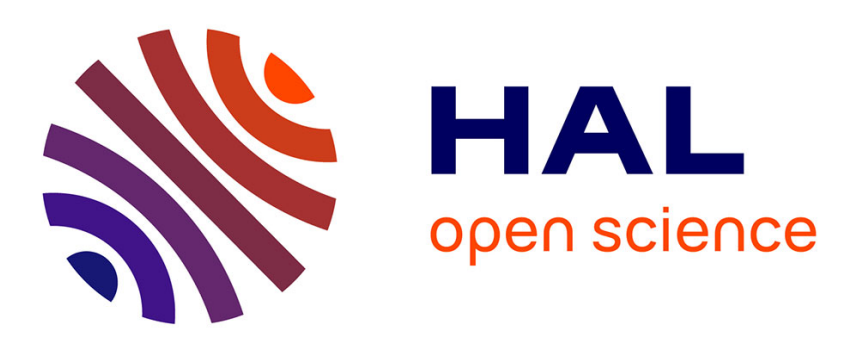

\title{
Are Myriophyllum alterniflorum biomarker responses to arsenic stress differentially affected by hydrodynamic conditions?
}

Maha Krayem, Véronique Deluchat, Philippe Hourdin, Pascal Labrousse

\section{To cite this version:}

Maha Krayem, Véronique Deluchat, Philippe Hourdin, Pascal Labrousse. Are Myriophyllum alterniflorum biomarker responses to arsenic stress differentially affected by hydrodynamic conditions?. Chemosphere, 2019, 225, pp.497 - 506. 10.1016/j.chemosphere.2019.03.065 . hal-03484784

\author{
HAL Id: hal-03484784 \\ https://hal.science/hal-03484784
}

Submitted on 20 Dec 2021

HAL is a multi-disciplinary open access archive for the deposit and dissemination of scientific research documents, whether they are published or not. The documents may come from teaching and research institutions in France or abroad, or from public or private research centers.
L'archive ouverte pluridisciplinaire HAL, est destinée au dépôt et à la diffusion de documents scientifiques de niveau recherche, publiés ou non, émanant des établissements d'enseignement et de recherche français ou étrangers, des laboratoires publics ou privés.

\section{(ㅇ)(1) $\$$}

Distributed under a Creative Commons Attribution - NonCommerciall 4.0 International 
4 Maha Krayem ${ }^{\mathrm{a}, \mathrm{b}}$, Véronique Deluchat ${ }^{\mathrm{a}}$, Philippe Hourdin ${ }^{\mathrm{a}}$, Pascal Labrousse ${ }^{\mathrm{a}}$

b Lebanese University, Platform for Research and Analysis in Environmental Sciences, Doctoral

8 School of Sciences and Technologies, P.O. Box 5, Hadath, Beirut, Lebanon.

9

Corresponding author:

Pascal Labrousse

pascal.labrousse@unilim.fr

Phone: +33(0)5 55435841

University of Limoges, Faculty of Pharmacy, FR 3503, PEIRENE EA 7500 - Laboratory of 


\section{Abstract}

Arsenic (As) is a significant contaminant in the environment and its detection through macrophytes can provide a powerful tool. Myriophyllum alterniflorum constitutes a good candidate by virtue of its ability to accumulate contaminants, and moreover its biomarkers can respond to the presence of trace metals and metalloids. The objective of this study therefore is to evaluate the watermilfoil response to As exposure under several hydrodynamic conditions since it is well known that hydrodynamics affect plant functioning. For this purpose, fresh watermilfoil plants are subjected to three hydrodynamic conditions, namely laminar, turbulent and calm, in a synthetic medium either enriched or not by $100 \mu \mathrm{g} . \mathrm{L}^{-1}$ arsenic for 21 days. Growth, pigment content (chlorophyll a, b and carotenoids), respiratory and photosynthetic activities, osmotic potential and hydrogen peroxide concentration are all monitored. Arsenic accumulation is measured separately in the roots and shoots of Myriophyllum alterniflorum. On the one hand, it should be noted that arsenic induces: (i) a significant increase in $\mathrm{H}_{2} \mathrm{O}_{2}$ content; (ii) a decrease in osmotic potential, pigment content, photosynthesis and respiration rates, shoot and root growth; and (iii) an inhibition of shoot branching. Moreover, a higher accumulation of this metalloid in roots than in shoots, regardless of the hydrodynamic condition, is witnessed. While on the other hand, hydrodynamic conditions only affect watermilfoil morphology and arsenic accumulation. Also, the younger and older parts have experienced differential toxic effects. Overall, our results suggest the effective use of $M$. alterniflorum in both water quality biomonitoring and phytoremediation studies.

Keywords: Alternate watermilfoil, biological and physiological endpoints, arsenic, hydrodynamic conditions, oxidative stress. 
43

44

45

46

47

48

49

50

51

52

53

54

55

56

57

58

59

60

61

62

63

Abbreviations:

LQ: limit of quantification

MTES: France's Ministry for the Ecological and Solidarity Transition

FW: fresh weight

DW: dry weight

SL: mean total main shoot length

RamifL: mean total length of shoot ramifications

RL: mean total root length.

\section{1- Introduction}

Arsenic (As), a metalloid with atomic number 33 and a molar mass of 74.92 g.mol $^{-1}$, constitutes nearly $0.00021 \%$ of the natural elements of the earth's crust. Its critical concentration in streams is $4.2 \mu \mathrm{g} . \mathrm{L}^{-1}$ (MTES and French Water Agencies, 2003). Arsenic has natural sources like volcanism, wildfires, and the weathering of bedrock regions that contributes to dispersing primary arsenic minerals like arsenopyrite $(\mathrm{FeAsS})$, realgar $(\mathrm{AsS})$ and orpiment $\left(\mathrm{As}_{2} \mathrm{~S}_{3}\right)$, known to form a geochemical background. The main sources of arsenic are industrial and agricultural uses, including (gold) mining and smelting activities, the combustion of municipal solid wastes and coal fly ash, pharmaceutical wastes, and the use of arsenic pesticides (Laperche et al., 2003; Punshon et al., 2017). Four degrees of oxidation have been identified for As, i.e.: -III, 0, +III, and $+\mathrm{V}$. The toxicity of As compounds decreases as follows: $\mathrm{AsH}_{3}$ gas $>$ As (-III) $>$ As (III) $>$ As (V) > methylated compounds (Sharma and Sohn, 2009). In addition, arsenic can be 
distinguished in: (i) organic forms, which are mainly arsenobetaine, arsenocholine and monoand di-methyl derivatives; and (ii) inorganic compounds constituted primarily of arsenite (AsIII) and arsenate (AsV) (Farooq et al., 2016; Singh et al., 2015; Tangahu et al., 2011). The speciation and mobility of arsenic in water are related to both $\mathrm{pH}$ and oxido-reduction potential. In natural waters, the main forms are arsenite under reducing conditions in groundwater and arsenate in surface waters (Cullen and Reimer, 1989; Villaescusa and Bollinger, 2008).

Arsenic as a non-essential element for plant growth has no specific and selective transporters $(\mathrm{Li}$ et al., 2016). Due to the arsenate/phosphate analogy, arsenate uptake in plant cells occurs via the phosphate transport system (Bakhat et al., 2017; Farooq et al., 2016). In aqueous solutions, arsenate, an oxyanion, actually exists in three forms, with corresponding pKa values $(2.2,7.0$ and 11.5) similar to phosphate pKa (2.1, 7.2 and 12.7) (Elias et al., 2012; Tawfik and Viola, 2011). In plants, arsenic is preferentially accumulated in roots (Mazej and Germ, 2009; Vromman et al., 2011; Yabanli et al., 2014). It is well known that As reduces photosynthesis and growth, destroys the chloroplast membrane, reduces chlorophyll synthesis, produces reactive oxygen species (ROS) in leading to deleterious effects in cells (membranes, DNA, photosynthetic pigments) and lastly decreases osmotic potential (Cao et al., 2004; da-Silva et al., 2017; Li et al., 2011; Meharg and Macnair, 1992; Mkandawire and Dudel, 2005; Patra et al., 2004; Rahman et al., 2007b; Robinson et al., 2006; Stoeva et al., 2005; Stoeva and Bineva, 2003; Krayem et al., 2017).

The bioindication of water pollution has been using aquatic macrophytes for several decades (Lagadic et al., 1998), and this process became incorporated into the European Water Framework Directive (Aguiar et al., 2014; Delmail, 2014). Aquatic macrophytes may be impacted not only by the toxic effects of xenobiotics (Pollard et al., 2014) but also by other biotic and abiotic factors, such as hydrodynamic conditions (Atapaththu et al., 2015; Atapaththu 
and Asaeda, 2015) or nutrient enrichment (Krayem et al., 2016a, 2016b). It has been demonstrated that water movement plays a key role since it regulates freshwater macrophyte metabolism and growth (Madsen et al., 2001). Furthermore, mechanical stresses leading to hormonal imbalance, ROS generation or lipoperoxidation can be generated by water movement (Ellawala et al., 2013, 2011). To reinforce the use of macrophyte biomarkers in environmental conditions, the interactions between aquatic plants and these environmental factors must be elucidated.

Myriophyllum alterniflorum, also known as alternate watermilfoil, is a submerged aquatic macrophyte found in European inland oligotrophic freshwaters. As demonstrated previously, watermilfoil can accumulate metal or metalloid like copper, cadmium and arsenic (Decou et al., 2019, 2018; Delmail et al., 2011a, 2011b; Krayem et al., 2016b, 2018); until now however, the effect of hydrodynamics on the physiology of submerged macrophytes has rarely been evaluated (Atapaththu et al., 2015; Atapaththu and Asaeda, 2015). In watermilfoil, arsenic could induce a stress leading to a change in biochemical, physiological and morphological biomarkers. In addition, arsenic stress may be modulated by hydrodynamic conditions affecting this macrophyte in the stream.

The aim of this study therefore is to evaluate the combined effect of arsenic stress and hydrodynamics on the response of watermilfoil biomarkers. Moreover, the influence of hydrodynamic conditions on arsenic accumulation is determined and the effects of this accumulation in Myriophyllum alterniflorum roots and shoots are investigated.

\section{Materials and methods}

\subsection{Plant material, growth conditions and acclimation}


The M. alterniflorum strain was previously established by Delmail et al. (2011a). After 30 days of proliferation in Murashige and Skoog medium (Murashige and Skoog, 1962), the plant clones were acclimatized for 21 days in Vienne oligotrophic synthetic medium (Krayem et al., 2016a, 2016b, 2018) (the Vienne oligotrophic medium composition is given in the Supplementary Data). Nitrate, ammonium and phosphate concentrations were fixed according to the system of surface water quality evaluation (MTES and French Water Agencies, 2003) at $2 \mathrm{mg} . \mathrm{L}^{-1}(32 \mu \mathrm{M})$, $0.1 \mathrm{mg} . \mathrm{L}^{-1}(5.5 \mu \mathrm{M})$ and $0.1 \mathrm{mg} . \mathrm{L}^{-1}(1.05 \mu \mathrm{M})$, respectively. Plant acclimation was performed in a culture box (Steri Vent High Model $80 \times 100 \times 100 \mathrm{~mm}$, KALYS SA) containing $400 \mathrm{~mL}$ of sterilized medium $\left(20 \mathrm{~min}, 121^{\circ} \mathrm{C}\right.$ in an autoclave (DB-90, Systec)) and maintained in a growth cabinet set at $26^{\circ} \pm 2^{\circ} \mathrm{C}$, with a 16 -h photoperiod and a light intensity of $13.1 \pm 0.6 \mathrm{~W} . \mathrm{cm}^{-2}$ (Supra'Lux, Actizoo, $30 \mathrm{~W}$ ).

\subsection{Experimental set-up}

In order to simulate environmental conditions, an aquarium system was created with water recirculation (see Fig. 1 in the Supplementary Data). Each aquarium $(\mathrm{L}=120 \mathrm{~cm}$; W=40 cm, $\mathrm{H}=49 \mathrm{~cm}$ ) was filled with $150 \mathrm{~L}$ of Vienne oligotrophic synthetic medium (see composition in the Supplementary Data). The treated aquarium was supplemented with $100 \mu \mathrm{g} \cdot \mathrm{L}^{-1}$ of As (V) $\mathrm{Na}_{2} \mathrm{HAsO}_{4}, 7 \mathrm{H}_{2} \mathrm{O}$ (Normapur, Prolabo 99.9\%), while another aquarium with no added arsenic served as the control. A channel (pipe half-sectioned in the lengthwise direction, $\mathrm{L}=135 \mathrm{~cm}$; $=16.5 \mathrm{~cm}$ ) was installed over the aquarium. Inside the aquarium, a pump (Laguna power jet, $7600 \mathrm{~L} / \mathrm{h}, 75 \mathrm{~W})$ transferred water from the aquarium to the top of the channel, allowing water to cascade into the aquarium at the bottom of the channel. Three distinct hydrodynamic zones were thus created in this system, namely: calm (in the aquarium), turbulent (at the waterfall from the channel into the aquarium), and laminar (in the channel with a water velocity of approx. $3 \mathrm{~cm} . \mathrm{s}^{-}$ 
$\left.{ }^{1}\right)$. In each zone, 35 grams of fresh watermilfoil were exposed. The younger and older parts of watermilfoils shoots were distinguished. For a morphological biomarker analysis, six node explants (six replicates) were affixed onto a Plexiglas square $(10 \mathrm{~cm} \times 10 \mathrm{~cm})$ in two hydrodynamic zones, an intermediate zone and a laminar zone, for 19 days. Three independent experiments were conducted and for each experiment, at least three replicates were analyzed. (For more details about the experimental set-up, see Supplementary Data.)

\subsection{Arsenic monitoring}

The As concentrations in plants (roots and shoots) were determined by means of ICP-MS (Agilent Technology, ICP-MS 7700). SLRS-5 (river water reference for trace metals, density = $1.0007 \mathrm{~g} . \mathrm{mL}^{-1}$ ) was used as the certified reference for purposes of analysis, with a limit of quantification (LQ) $=0.05 \mu \mathrm{g}$ As. $\mathrm{L}^{-1} .500 \mathrm{mg}$ of fresh watermilfoil were therefore dried at $60^{\circ} \mathrm{C}$ for $48 \mathrm{~h}$ and then digested in $4 \mathrm{~mL}$ of a mixture of $\mathrm{HNO}_{3}$ (Xilab for trace element analysis, 69\%) and $\mathrm{H}_{2} \mathrm{O}_{2}$ (Prolabo, 30\%) $\left(50 / 50 \mathrm{v} / \mathrm{v}\right.$ ) at $150^{\circ} \mathrm{C}$ for $2 \mathrm{~h}$, adjusted afterwards to $10 \mathrm{~mL}$ with MilliQ-Water and filtered with a $0.2-\mu \mathrm{m}$ syringe filter $(0.2 \mu \mathrm{m}$, Whatman). The Bioconcentration Factor (BCF) was calculated by applying Equation 1:

$$
\mathrm{BCF}\left({\mathrm{L} . \mathrm{kg}^{-1}}^{-1}=[\mathrm{M}] \text { plants } /[\mathrm{M}] \text { water }(\text { Eq. 1) }\right.
$$

where $[\mathrm{M}]$ plants is defined as the metal concentration in plants (shoots or roots), in $\mu \mathrm{g} \cdot \mathrm{kg}^{-1} \mathrm{FW}$, and $[\mathrm{M}]$ water the metal concentration in water, in $\mu \mathrm{g} \cdot \mathrm{L}^{-1}$. All these calculations were performed on three replicates of plants and water samples in each of the three independent experiments.

\subsection{Biomarker analysis}

\subsubsection{Biochemical biomarkers}


156

157

The $\mathrm{H}_{2} \mathrm{O}_{2}$ content was measured according to Zhou et al. (2006); details are provided in the Supplementary Data.

\subsubsection{Chlorophyll a, $b$ and carotenoid contents}

Pigment quantification was based on the methods implemented by Delmail et al. (2011a), with these experimental conditions also being detailed in the Supplementary Data.

\subsubsection{Physiological biomarkers}

\subsubsection{Osmotic potential ( $\Psi$ scor)}

The osmotic potential ( $\Psi \mathrm{s})$ was measured using a vapor pressure osmometer (Micro Osmometer Manual, Löser Messtechnek) and in accordance with the method implemented by Krayem et al. (2018). Further details are provided in the Supplementary Data.

\subsubsection{Photosynthetic and respiration rates}

For each independent experiment, both photosynthetic and respiration rates were measured on three replicates at 1 and 21 days in an aquarium system using a Clark-type oxygen electrode (DW 1 Oxygen Electrode Chamber, Hansatech Instruments, Ltd.) and by following the method detailed in the Supplementary Data.

\subsubsection{Morphological biomarkers}

For each independent experiment, six watermilfoil shoots affixed onto Plexiglas squares were monitored in an aquarium for 19 days. Two squares per aquarium were laid out in the intermediate and laminar zones, as previously described in Section 2.2. For each square, the mean total main shoot length (SL), mean total length of shoot ramifications (RamifL) and mean 
total root length (RL) were measured on plant pictures taken by a Sony camera (14 M pixels) every third day, then analyzed with the Visilog Viewer 6.8 software (NOESIS).

\subsection{Statistical analysis}

For each independent experiment and for each hydrodynamic zone, our results relied on three replicates $(\mathrm{N}=3)$, except for the growth parameters, which were based on six replicates $(\mathrm{N}=6)$. Data normality was verified by a kernel density estimation, along with typical Lilliefors and Shapiro tests. The effects of As on pigment content, hydrogen peroxide, osmotic potential and morphology at 21 days were assessed by the mixed ANOVA method, followed by a Sidak test to compare differences between control plants and arsenic-treated plants, as well as between younger and older plant parts. Arsenic accumulation in the various plant parts and the bioconcentration factor $(\mathrm{BCF})$ were both tested by means of the Bonferonni test. All tests were performed at a 5\% significance level using the Systat 11 software package for Windows.

\section{Results and discussion}

\subsection{As internalization in watermilfoil}

Arsenic concentrations ranged between 200 and $500 \mu \mathrm{g} \cdot \mathrm{g}^{-1}$ plant dry weight (DW) in this experiment, while they only reached $150 \mu \mathrm{g} \cdot \mathrm{g}^{-1} \mathrm{DW}$ in a previous box experiment (Krayem et al., 2016a) conducted at 21 days of exposure for each system (Table 1). This higher arsenic accumulation in watermilfoil from the aquarium system was mainly due to the higher level of exposure to arsenic. If the arsenic concentration was indeed identical $\left(100 \mu \mathrm{g} . \mathrm{L}^{-1}\right)$ in the two systems (150-L aquarium and 400-mL boxes), then the biomass/As ratio in the aquarium was 89 times higher than in the boxes.

In addition, hydrodynamics affected the differential accumulation of arsenic by roots and shoots. A $57 \%, 57 \%$ and $44 \%$ higher As accumulation in roots than in shoots was recorded (p-value = 
0.001) under calm, turbulent and laminar conditions, respectively. These results were also assessed by calculating the BCFs in roots and shoots within each of the three hydrodynamic zones. A $58 \%$ and $51 \%$ higher BCF (see Table 1) in roots than in shoots was recorded in the calm and turbulent zones, respectively. Similarly, in the laminar zone, a $45 \%$ increase in the BCF in roots, compared to shoots, was found. It appears that in roots, As accumulation was highest in the calm zone. An increase in the arsenic content of roots located in the calm zone, by about $8 \%$ and $23 \%$, was noted compared to the turbulent and laminar zones, respectively. It could be hypothesized that these differences in As accumulation are correlated with water flow velocity. It could indeed be assumed that changes in water velocity affect plant metabolism and growth, as has been reported by many authors (for a comprehensive review, see Bornette and Puijalon, 2011; Franklin et al., 2008). For example, Strand and Weisner (2001) indicated that M. spicatum at sheltered sites increase (or at least do not decrease) their below-ground biomass. This greater allocation to below-ground organs could influence absorption and explain the increase in arsenic content observed in our experiment. Moreover, as reported by Franklin et al. (2008), photosynthetic and nutrient uptake rates are positively correlated with low water velocity $(0-0.1$ $\left.\mathrm{m} . \mathrm{s}^{-1}\right)$. Accordingly, our results on M. alterniflorum should be explored by further experiments since the influence of flow velocity on aquatic macrophytes is a very complex process. It is well documented that at moderate water flow rates as velocity increases, the diffusive boundary layer around the plant surface erodes more substantially, thus leading to enhanced nutrient and gas fluxes and hence photosynthesis and growth. In contrast, Franklin et al. (2008) indicated that $M$. spicatum belong to the species most susceptible to increased velocity due to high hydraulic resistance and low anchoring strength. Increasing the velocity actually leads to physical and 
mechanical stresses due to greater drag forces, which in turn can lead to stem breakage and uprooting.

In conclusion, a higher flow velocity induces the lowest As accumulation in roots, while in shoots, the As level was practically similar across the three hydrodynamic zones. The BCF was higher in roots than in shoots for all three conditions and higher in the calm zone, whereas the shoot/root ratio was lower in the laminar zone than in the two other zones (1.77 vs. 2.29). Arsenic is a non-essential element for plants, and it is well known that the root endodermis constitutes a barrier to the root-to-shoot translocation of toxic contaminants (Mazhoudi et al., 1997). In addition, several studies have pointed to roots as the preferential site of arsenic accumulation in plants (Mazej and Germ, 2009; Vromman et al., 2011; Yabanli et al., 2014). A BCF of 4,000 L.kg-1 (based on dry matter) was observed in the roots of Hydrilla verticillata after exposure to $0.15 \mu \mathrm{g} . \mathrm{L}^{-1}$ of arsenic for 4 days (Xue and Yan, 2011). Mazej and Germ (2009) found a BCF of $1.5{\mathrm{~L} . \mathrm{kg}^{-1}}^{-1}$ in the roots, compared with a BCF of $0.045 \mathrm{~L}^{\mathrm{kg}} \mathrm{g}^{-1}$ in the shoots, of Najas marina after a treatment with $10.6 \mathrm{mg} / \mathrm{kg}$ of arsenic in the sediment. This reduced root-toshoot transfer of arsenic may be due to phytochelatin-mediated As vacuolar sequestration in root cells (Gupta et al., 2004; Hasanuzzaman et al., 2015; Zhao et al., 2009).

\subsection{Biomarker analysis}

\subsubsection{Biochemical biomarkers}

\subsubsection{1 $\mathrm{H}_{2} \mathrm{O}_{2}$ content}

$\mathrm{H}_{2} \mathrm{O}_{2}$ content was not affected by the hydrodynamic conditions in control plants (Fig. 1). When comparing young and old parts, as opposed to As-treated plants, the control plants did not display any significant difference $(\mathrm{p}$-value $=0.154)$. At 21 days, in the As-treated plants, a 
significant increase in $\mathrm{H}_{2} \mathrm{O}_{2}$ content of $96 \%, 106 \%$ and $100 \%$ (p-value $=0.001$ ) in the young parts and $85 \%, 140 \%$ and $83 \%(\mathrm{p}$-value $=0.004)$ in the old parts of As-exposed plants, compared to the control specimens, were observed for the calm, turbulent and laminar zones, respectively (Fig. 1). Arsenic toxicity appears on the tissues of both young and old parts, generating an oxidative stress characterized by the formation of hydrogen peroxide (Hasanuzzaman et al., 2015; Mallick et al., 2011).

In contrast, at 21 days in As-treated plants, a significant increase in $\mathrm{H}_{2} \mathrm{O}_{2}$ content of $28 \%$, $49 \%$ and 29\% (p-value $=0.049)$ is observed in the older parts for the calm, turbulent and laminar zones, respectively (Fig. 1), as compared to the younger parts. Similarly, a higher As accumulation in older than younger fronds of the terrestrial plant Pteris vittata could be observed (7.575 $\mu$ gAs.g ${ }^{-1}$ DW / $4.893 \mu g$ As.g ${ }^{-1}$ DW) after 12 weeks of cultivation in $97 \mu g$ As.g $^{-1}$ soil. This differential accumulation appears to produce an As detoxification mechanism as older senescent leaves fall (Zhang et al., 2002). Bouazizi et al. (2010) discovered that, unlike in older leaves, hydrogen peroxide content remained stable in the young leaves of Phasoleus vulgaris watered with $3.2 \mathrm{mg} \cdot \mathrm{L}^{-1} \mathrm{Cu}$, thus suggesting a greater stimulation of peroxidase activity in older rather than younger tissues. Along the same lines, our results have suggested a higher oxidative stress in older shoots. This differential effect of As on older parts could be explained by the increased activity of the enzymatic antioxidant system (superoxide dismutase, ascorbate peroxidase, peroxidase) in younger parts, contributing to ROS limitation in order to protect young tissues from ROS degradation, i.e. a phenomenon previously observed in several species in response to various trace elements (da-Silva et al., 2017; Hasanuzzaman et al., 2015; Delmail and Labrousse, 2012). Another aspect could be the preferential As sequestration in old leaves to protect the younger ones. 
Pigment levels were not affected by the hydrodynamic conditions in control plants (Fig. 2). In As-treated plants, a significant decrease in pigment content, equal to $22 \%, 29 \%$ and $22 \%$ for Chl $\mathrm{a}(\mathrm{p}$-value $=0.026)($ Fig. 2$)$ and $31 \%, 23 \%$, and $10 \%$ for Chl b (p-value $=0.048)$, was observed

(Fig. 2) in the younger parts for the calm, turbulent and laminar zones, respectively. This reduction reached $22 \%, 24 \%$ and $18 \%$ for $\mathrm{Chl}$ a (p-value $=0.026)($ Fig. 2$)$ in the older parts compared to the control for the calm, turbulent and laminar zones, respectively. On the other hand, chlorophyll $\mathrm{b}$ in the older parts of the As-treated plants did not change significantly (pvalue $=0.091)$ over time compared to the controls for the three hydrodynamic zones, respectively (Fig. 2). In contrast, the carotenoid concentration (Fig. 2) did not differ significantly in the young shoots vs. the control ( $p$-value $=0.387$ ), whereas in old shoots a significant increase of approximately $25 \%$ (p-value $=0.014$ ) was observed for the calm, turbulent and laminar zones. Arsenic therefore caused a decrease of $\mathrm{Chl} a$ and $\mathrm{b}$, while the carotenoids only increased in the older parts. Duman et al. (2010) found in Lemna minor a decrease in chlorophyll pigment content during arsenic stress $\left(0.079-5.056 \mathrm{mg} . \mathrm{L}^{-1}\right.$ As $(\mathrm{V})$ in $400-\mathrm{mL}$ Hoagland medium over 6 days). Similarly, Ozturk et al. (2010) demonstrated this same feature in Nasturtium officinale (after exposing $4 \mathrm{~g}$ of plants to doses of $0.79 \mathrm{mg} \cdot \mathrm{L}^{-1}$ to $3.9 \mathrm{mg} \cdot \mathrm{L}^{-1}$ of $\mathrm{As}(\mathrm{III})$ in $400 \mathrm{~mL}$ of Hoagland medium for 7 days). Srivastava et al. (2013) indicated that in Hydrilla verticillata, exposure to $37.5 \mathrm{mg} . \mathrm{L}^{-1}$ As for 96 hours induced a $24 \%$ decrease in chlorophyll content.

The increase in carotenoid content observed in this study may however reflect one of the nonenzymatic defense mechanisms adopted by the plant to protect its chlorophyll pigments from oxidative degradation (Ferrat et al., 2003). In contrast, a 2-mg. $\mathrm{L}^{-1}$ arsenate exposure on two aquatic species, Vallisneria gigantea and Azolla filliculoides, induced an increase of fluorescence 
in the range of 400 to $500 \mathrm{~nm}$; this finding was correlated with an increase in the biosynthesis of carotenoids and flavonoids, i.e. two compounds occurring in the arsenic defense system (Iriel et al., 2015).

When comparing older and younger parts of watermilfoil under each hydrodynamic condition, a decrease of $26 \%, 38 \%$ and $38 \%(\mathrm{p}$-value $=0.002)$ for $\mathrm{Chl}$ a and $45 \%, 39 \%$, and $46 \%(\mathrm{p}$-value $=$ 0.009) for Chl b were observed in the older parts relative to the younger parts of the control plants in the calm, turbulent and laminar zones, respectively (Fig. 2). Similarly, in As-treated plants, a reduction of $26 \%, 33 \%$ and $35 \%$ for $\mathrm{Chl}$ a (p-value $=0.005)($ Fig. 2$)$ and $37 \%, 47 \%$ and 46\% (p-value $=0.003)$ for Chl b (Fig. 2) had also been recorded. Alternatively, the carotenoid contents remained stable in both the control specimens $(\mathrm{p}$-value $=0.959)$ and As-treated plants (p-value $=0.086)$ regardless of the hydrodynamic condition. Therefore, the As effect on older parts was greater than on younger ones, especially for chlorophylls a and $b$. The decrease in photosynthetic pigment contents could be due to: (i) lipid peroxidation by ROS and chloroplast membrane degradation (Upadhyay and Panda, 2009), (ii) chlorophyll degradation by chlorophyllase (Sharma and Dubey, 2005), or (iii) acceleration of a tissue aging process called "senescence" resulting in a decrease in pigment content due to resource remobilization (Delmail and Labrousse, 2012). The stability of the carotenoid contents in the younger parts and their increase in the older parts is reflected by the major role these contents play in defending and protecting the other pigments from oxidative degradation (Ferrat et al., 2003).

\subsubsection{Physiological biomarkers}

\subsubsection{Osmotic potential}


The hydrodynamic conditions did not affect the osmotic potential of control plants ( $p$-value $=$ 0.316). In addition, no significant difference was observed between younger and older parts in the control specimens $(\mathrm{p}$-value $=0.416)($ Fig. 3)

However, in As-treated plants (Fig. 3), significant decreases in osmotic potential of 37\%, $19 \%$ and $22 \%$ in the younger parts (p-value $=0.002)$ and $26 \%, 24 \%$ and $26 \%$ in the older parts (pvalue $=0.002$ ) were observed for the calm, turbulent and laminar zones, respectively (Fig. 3). The exposure of plants to arsenic can in fact cause an increase in the protein, soluble sugar, proline and glycine-betaine contents in vacuoles (Hasanuzzaman et al., 2015). This accumulation leads to an increase in solute concentrations and, consequently, contributes to decreased osmotic potential (Garg and Singla, 2011; Hasanuzzaman et al., 2015; Stoeva et al., 2005; Yabanli et al., 2014). Tripathi et al. (2014) studied the effect of increasing concentrations of As (V) from 0 to $18.5 \mathrm{mg} . \mathrm{L}^{-1}$ on the macrophyte Najas indica by measuring the amino acid concentration. They found that the total concentration of amino acids and proteins increased by $54 \%$ and $42 \%$ respectively after exposure to $18.5 \mathrm{mg} \cdot \mathrm{L}^{-1}$ of As over 2 days. This increase in the concentration of amino acids and proteins in plant cells could induce a decrease in osmotic potential and moreover explains the result obtained in this study. In addition, Srivastava et al. (2013) showed that Hydrilla verticillata reduced its water use and increased its transpiration during As exposure (37.5 mg. $\mathrm{L}^{-1}$ and after 96 hours). This reduction led to an increased solute concentration and hence a decrease in osmotic potential. Also, this result is similar to the observation by Delmail et al. (2011a) highlighting a $27 \%$ and $65 \%$ decrease in the osmotic potential of younger and older leaves of Myriophyllum alterniflorum during a 30-day exposure to $100 \mu \mathrm{g} \mathrm{Cu} . \mathrm{L}^{-1}$. Moreover, Krayem et al. (2018) reported a decrease in the osmotic potential of $22 \%, 16 \%$ and $20 \%$ in younger parts $(\mathrm{p}$-value $=0.008)$ and of $22 \%, 18 \%$, and $17 \%$ in older parts $(\mathrm{p}$-value $=0.008)$ 
compared to the control specimens in the calm, turbulent and laminar zones, respectively, in Myriophyllum alterniflorum plants after exposure to $100 \mu \mathrm{g} . \mathrm{Cu} . \mathrm{L}^{-1}$.

No significant difference between young and old parts was found for either the control group (pvalue $=0.416)$ or the As-treated plants ( $\mathrm{p}$-value $=0.420)$. In addition, there was no significant difference in osmotic potential across the three zones and between the control and As-treated plants $(p$-value $=0.388)$. Under our experimental conditions therefore, the effect of arsenic did not vary between the older and younger parts of watermilfoil. This result differs from the $38 \%$ decrease in osmotic potential observed in older leaves of Myriophyllum alterniflorum, compared to younger leaves, at 30 days of exposure to $100 \mu \mathrm{g} \mathrm{Cu} . \mathrm{L}^{-1}$, as reported by Delmail et al. (2011a), whose medium differed from ours, particularly in nitrates and phosphates, which could explain this discrepancy.

\subsubsection{Photosynthetic and respiratory activities}

No significant effect of hydrodynamic conditions on respiration and net photosynthesis (NP) in the control plants was observed (p-values $=0.138$ and 0.855 , respectively) (Fig. 4). In the Astreated plants however, a significant decrease in respiration, ranging from $30 \%$ to $50 \%$ (p-value $=0.001$ ), and in photosynthesis, ranging from $30 \%$ to $40 \%$ (p-value $=0.001$ ), was recorded on Day 1 and Day 21, respectively, within the three zones (Fig. 4).

The As toxicity clearly induced a response of watermilfoil biochemical and physiological biomarkers. Exposure to $143 \mu \mathrm{g}$ As.g ${ }^{-1} \mathrm{FW}$ led to a decrease in respiration and NP. The oxidative stress generated by arsenic can indeed destroy thylakoid membranes, thus reducing pigment contents and affecting the photosystem II (Prasad et al., 2001). Stoeva and Bineva (2003) showed that arsenic can induce chloroplast membrane destruction, leading to decreased photosynthesis. In Hydrilla verticillata, a $32 \mathrm{mg} . \mathrm{L}^{-1}$ As exposure for $96 \mathrm{~h}$ induced a decrease in 
net photosynthesis and in $\mathrm{Chl} \mathrm{a}, \mathrm{Chl} \mathrm{b}$ and Car contents (Srivastava et al., 2013). This reduction could be due to: (i) chlorophyll degradation by ROS, (ii) a reduction in photosystem II efficiency, and/or (iii) a dysfunction of the thylakoid electron transport chain (Duman et al., 2010; Hasanuzzaman et al., 2015; Rahman et al., 2007a). Furthermore, arsenic and especially As (V) can form a complex with adenosine diphosphate by means of phosphate substitution. ADPAs (V) inhibits the synthesis of the adenosine triphosphate (ATP) necessary for respiration in the mitochondrial electron transport chain as well as for photosynthesis in the thylakoid electron transport chain. Such a mechanism leads to a reduction of respiratory and photosynthetic activities in plant cells (Elias et al., 2012; Finnegan and Chen, 2012).

\subsubsection{Morphological biomarkers}

In As-treated plants, a significant decrease in shoot length (SL) (Fig. 5a) by $15 \%$ and $16 \%$ (pvalue $=0.0260)$ at 19 days was observed for the intermediate and laminar zones, respectively, compared to the control plants. Similarly, RL (Fig. 5b) decreased by 35\% and 52\% (p-value = 0.005) at $\mathrm{T}=19$ days of As exposure for the intermediate and laminar zones, respectively, relative to the control plants. This significant reduction in stem and root lengths reflects As toxicity (Hasanuzzaman et al., 2015). Gusman et al. (2013) observed a 38\% decrease in Lactuca sativa leaf length and a $50 \%$ decrease in root length after exposure to $3.4 \mathrm{mg} . \mathrm{L}^{-1}$ As. Liu et al. (2005) found a reduction in the length of the main stem and root of $3.9 \%$ and $8.6 \%$, respectively, after treating Triticum aestivum with $0.5 \mathrm{mg} . \mathrm{L}^{-1}$ As. In Pisum sativum after $24 \mathrm{~h}$ of exposure to $0.2 \mathrm{mg} . \mathrm{L}^{-1}$ As (V), Dho et al. (2010) observed that the root growth and mitotic index decreased by $42 \%$ and $20 \%$, respectively. This reduction in meristematic activity was correlated with ROS production affecting root cells mitosis. In addition, in Oryza sativa exposed to 7.8 and 15.6 mg.L $\mathrm{L}^{-1}$ As for 24 h, Singh et al. (2009) recorded a 23\% and 37\% decrease in root length; these 
authors also noted a $81 \%$ and $30 \%$ increase in peroxyl radical $\mathrm{O}_{2}^{-*}$ and hydrogen peroxide at $15.6 \mathrm{mg} . \mathrm{L}^{-1}$ As. As previously observed in the literature, oxidative stress due to As could thus occur in roots, decreasing root length after an exposure to $100 \mu \mathrm{g}$ As (V). $\mathrm{L}^{-1}$.

No shoot branching was observed in control and As-treated plants in both hydrodynamic zones.

In addition, a significant decrease in SL (p-value $=0.05)$ and $R L(p$-value $=0.001)$ was noted in plants from the intermediate zone as compared to the laminar zone (Figs. 5a, b). As previously pointed out, flow velocity exerts a significant effect on macrophyte growth, from a stimulating effect at low and moderate velocities to an inhibiting effect at higher velocities; moreover, water movement could generate physical and mechanical stresses, in inducing morphological changes like dwarfed growth form (Bornette and Puijalon, 2011; Franklin et al., 2008; Madsen et al., 2001). It should be noted that water turbulence can affect growth more drastically than laminar flow, as demonstrated in Elodea nuttallii by Atapaththu and Asaeda (2015). Water turbulence can induce chlorosis, plasmolysis in leaf cells, and the accumulation of organic acids (like citrate, oxalate and ascorbate) and amino acids, which could interfere with cell metabolism and inhibit plant growth (Atapaththu et al., 2015; Atapaththu and Asaeda, 2015). Lastly, these authors also reported ultrastructural changes, such as starch granule accumulation in chloroplasts and cell wall thickening linked to cellulose and lignin accumulation.

\section{Conclusion}

In our study, hydrodynamics did not influence the response of the watermilfoil biomarkers tested, except for the growth parameters; this response of several aquatic macrophytes species to water movement is well known since water velocities and turbulence induce mechanical stress 
and lead to a decline in plant growth. Hydrodynamics did however affect arsenic accumulation and acted differentially on the roots and shoots. The arsenic concentration observed in roots was higher than that in shoots, most likely resulting from a mixed response of water velocity inducing a below-ground biomass accumulation along with stress-inducing As sequestration in the vacuoles of root cells. In this manner, the watermilfoil protected its shoots from As toxicity, and particularly the younger parts since As accumulation and toxicity biomarker responses are higher in the older parts.

Further studies are needed to determine the exact contribution of flow velocity, water turbulence and trace element stress on aquatic macrophyte biomarkers.

\section{Acknowledgments}

This research was financially supported by the European Union through the FEDER-Plan Loire Research Program 38200. The authors would also like to acknowledge the support of the AZM and SAADE associations, PCSI programs in AUF (Francophonie University Association), and Limoges University. Thanks are also addressed to Karine Cleries, Marion Rabiet, Jean-François Lenain, Michel Botineau, Sophie Lissalde, Patrice Fondanèche, Florence Lecavelier Des Etangs, Christian Moesch, Véronique Kazpard and Zeinab Saad for their technical assistance and critical reading of the manuscript. 
425

426

427

\section{References}

Aguiar, F.C., Segurado, P., Urbanič, G., Cambra, J., Chauvin, C., Ciadamidaro, S., Dörflinger, G., Ferreira, J., Germ, M., Manolaki, P., Minciardi, M.R., Munné, A., Papastergiadou, E., Ferreira, M.T., 2014. Comparability of river quality assessment using macrophytes: A multi-step procedure to overcome biogeographical differences. Sci. Total Environ. 476477, 757-767. https://doi.org/10.1016/j.scitotenv.2013.10.021

Atapaththu, K.S.S., Asaeda, T., 2015. Growth and stress responses of Nuttall's waterweed Elodea nuttallii (Planch) St. John to water movements. Hydrobiologia 747, 217-233. https://doi.org/10.1007/s10750-014-2141-9

Atapaththu, K.S.S., Miyagi, A., Atsuzawa, K., Kaneko, Y., Kawai-Yamada, M., Asaeda, T., 2015. Effects of water turbulence on variations in cell ultrastructure and metabolism of amino acids in the submersed macrophyte, Elodea nuttallii (Planch.) H. St. John. Plant Biol. 17, 997-1004. https://doi.org/10.1111/plb.12346

Bakhat, H.F., Zia, Z., Fahad, S., Abbas, S., Hammad, H.M., Shahzad, A.N., Abbas, F., Alharby, H., Shahid, M., 2017. Arsenic uptake, accumulation and toxicity in rice plants: Possible remedies for its detoxification: A review. Environ. Sci. Pollut. Res. 24, 9142-9158. https://doi.org/10.1007/s11356-017-8462-2

Bornette, G., Puijalon, S., 2011. Response of aquatic plants to abiotic factors: a review. Aquat. Sci. 73, 1-14. https://doi.org/10.1007/s00027-010-0162-7

Bouazizi, H., Jouili, H., Geitmann, A., El Ferjani, E., 2010. Copper toxicity in expanding leaves of Phaseolus vulgaris L.: antioxidant enzyme response and nutrient element uptake. Ecotoxicol. Environ. Saf. 73, 1304-1308. https://doi.org/10.1016/j.ecoenv.2010.05.014 
Cao, X., Ma, L.Q., Tu, C., 2004. Antioxidative responses to arsenic in the arsenichyperaccumulator Chinese brake fern (Pteris vittata L.). Environ. Pollut. 128, 317-325. https://doi.org/10.1016/j.envpol.2003.09.018

Cullen, W.R., Reimer, K.J., 1989. Arsenic speciation in the environment. Chem. Rev. 89, 713764. https://doi.org/10.1021/cr00094a002

da-Silva, C.J., Canatto, R.A., Cardoso, A.A., Ribeiro, C., Oliveira, J.A., 2017. Arsenichyperaccumulation and antioxidant system in the aquatic macrophyte Spirodela intermedia W. Koch (Lemnaceae). Theor. Exp. Plant Physiol. 29, 203-213. https://doi.org/10.1007/s40626-017-0096-8

Decou, R., Bigot, S., Hourdin, P., Delmail, D., Labrousse, P., 2019.Comparative in vitro/in situ approaches to three biomarker responses of Myriophyllum alterniflorum exposed to metal stress. Chemosphere 222:29-37. https://doi.org/10.1016/j.chemosphere.2019.01.105

Decou, R., Laloi, G., Zouari, M., Labrousse, P., Delmail, D., 2018. Evaluation of the Relevance of Myriophyllum alterniflorum (Haloragaceae) Cadmium-Sensitive Biomarkers for Ecotoxicological Surveys. Bull Environ Contam Toxicol. 101 (4):458-466 https://doi.org/10.1007/s00128-018-2433-2

Delmail, D., 2014. Risk management of European inland waters using macrophyte biomonitoring. Front. Environ. Sci. 2. https://doi.org/10.3389/fenvs.2014.00031

Delmail, D., Labrousse, P., 2012. Plant ageing, a counteracting agent to xenobiotic stress, in: Nagata, T. (Ed.), Senescence. InTech. https://doi.org/10.5772/31944

Delmail, D., Labrousse, P., Hourdin, P., Larcher, L., Moesch, C., Botineau, M., 2011a. Differential responses of Myriophyllum alterniflorum DC (Haloragaceae) organs to 
copper: physiological and developmental approaches. Hydrobiologia 664, 95-105. https://doi.org/10.1007/s10750-010-0589-9

Delmail, D., Labrousse, P., Hourdin, P., Larcher, L., Moesch, C., Botineau, M., 2011 b. Physiological, anatomical and phenotypical effects of a cadmium stress in different-aged chlorophyllian organs of Myriophyllum alterniflorum DC (Haloragaceae). Environ. Exp. Bot. 72, 174-181. https://doi.org/10.1016/j.envexpbot.2011.03.004

Delmail, D., Labrousse, P., Hourdin, P., Larcher, L., Moesch, C., Botineau, M., 2011c. Differential responses of Myriophyllum alterniflorum DC (Haloragaceae) organs to copper: physiological and developmental approaches. Hydrobiologia 664, 95-105. https://doi.org/10.1007/s10750-010-0589-9

Dho, S., Camusso, W., Mucciarelli, M., Fusconi, A., 2010. Arsenate toxicity on the apices of Pisum sativum L. seedling roots: Effects on mitotic activity, chromatin integrity and $\begin{array}{lllll}\text { microtubules. } & \text { Environ. } & \text { Exp. } & \text { Bot. } & \text { 69, }\end{array}$ https://doi.org/10.1016/j.envexpbot.2010.02.010

Duman, F., Ozturk, F., Aydin, Z., 2010. Biological responses of duckweed (Lemna minor L.) exposed to the inorganic arsenic species As(III) and As(V): effects of concentration and duration of exposure. Ecotoxicology 19, 983-993. https://doi.org/10.1007/s10646-010$0480-5$

Elias, M., Wellner, A., Goldin-Azulay, K., Chabriere, E., Vorholt, J.A., Erb, T.J., Tawfik, D.S., 2012. The molecular basis of phosphate discrimination in arsenate-rich environments. Nature 491, 134-137. https://doi.org/10.1038/nature11517 
Ellawala, C., Asaeda, T., Kawamura, K., 2013. Water movement induced variations in growth regulation and metabolism of freshwater macrophyte Vallisneria spiralis L. in early growth stages. Hydrobiologia 709, 173-182. https://doi.org/10.1007/s10750-013-1447-3

Ellawala, C., Asaeda, T., Kawamura, K., 2011. Influence of flow turbulence on growth and indole acetic acid and $\mathrm{H}_{2} \mathrm{O}_{2}$ metabolism of three aquatic macrophyte species. Aquat. Ecol. 45, 417-426. https://doi.org/10.1007/s10452-011-9364-х

Farooq, M.A., Islam, F., Ali, B., Najeeb, U., Mao, B., Gill, R.A., Yan, G., Siddique, K.H.M., Zhou, W., 2016. Arsenic toxicity in plants: Cellular and molecular mechanisms of its transport and metabolism. Environ. Exp. Bot. 132, 42-52. https://doi.org/10.1016/j.envexpbot.2016.08.004

Ferrat, L., Pergent-Martini, C., Roméo, M., 2003. Assessment of the use of biomarkers in aquatic plants for the evaluation of environmental quality: application to seagrasses. Aquat. Toxicol. 65, 187-204. https://doi.org/10.1016/S0166-445X(03)00133-4

Finnegan, P.M., Chen, W., 2012. Arsenic Toxicity: The Effects on Plant Metabolism. Front. Physiol. 3. https://doi.org/10.3389/fphys.2012.00182

Franklin, P., Dunbar, M., Whitehead, P., 2008. Flow controls on lowland river macrophytes: A review. Sci. Total Environ. 400, 369-378. https://doi.org/10.1016/j.scitotenv.2008.06.018

Garg, N., Singla, P., 2011. Arsenic toxicity in crop plants: physiological effects and tolerance mechanisms. Environ. Chem. Lett. 9, 303-321. https://doi.org/10.1007/s10311-011-03137

Gupta, D.K., Tohoyama, H., Joho, M., Inouhe, M., 2004. Changes in the levels of phytochelatins and related metal-binding peptides in chickpea seedlings exposed to arsenic and different heavy metal ions. J. Plant Res. 117, 253-256. https://doi.org/10.1007/s10265-004-0152-8 
Gusman, G.S., Oliveira, J.A., Farnese, F.S., Cambraia, J., 2013. Arsenate and arsenite: the toxic effects on photosynthesis and growth of lettuce plants. Acta Physiol. Plant. 35, 12011209. https://doi.org/10.1007/s11738-012-1159-8

Hasanuzzaman, M., Nahar, K., Hakeem, K.R., Öztürk, M., Fujita, M., 2015. Arsenic toxicity in plants and possible remediation, in: soil remediation and plants. Elsevier, pp. 433-501.

Iriel, A., Dundas, G., Fernández Cirelli, A., Lagorio, M.G., 2015. Effect of arsenic on reflectance spectra and chlorophyll fluorescence of aquatic plants. Chemosphere 119, 697-703. https://doi.org/10.1016/j.chemosphere.2014.07.066

Krayem, Baydoun, M., Deluchat, V., Lenain, J.-F., Kazpard, V., Labrousse, P., 2016a. Absorption and translocation of copper and arsenic in an aquatic macrophyte Myriophyllum alterniflorum DC. in oligotrophic and eutrophic conditions. Environ. Sci. Pollut. Res. 1-8. https://doi.org/10.1007/s11356-016-6289-x

Krayem, Deluchat, V., Rabiet, M., Cleries, K., Lenain, J.F., Saad, Z., Kazpard, V., Labrousse, P., 2016b. Effect of arsenate As (V) on the biomarkers of Myriophyllum alterniflorum in oligotrophic and eutrophic conditions. Chemosphere 147, 131-137. https://doi.org/10.1016/j.chemosphere.2015.12.093

Krayem M., Deluchat V., Decou R., and Labrousse P, 2017. The arsenic in aquatic environments: the plant's point of view. Chapter 1 in Arsenic: risks of exposure, behavior in the environment, and toxicology. Knežević R, editor. Hauppauge, New York: Nova Science Publishers, Inc; 2017. (Chemistry research and applications).

Krayem, M., Deluchat, V., Hourdin, P., Fondanèche, P., Lecavelier Des Etangs, F., Kazpard, V., Moesch, C., Labrousse, P., 2018. Combined effect of copper and hydrodynamic 
conditions on Myriophyllum alterniflorum biomarkers. Chemosphere 199, 427-434. https://doi.org/10.1016/j.chemosphere.2018.02.050

537

538

539

540

Lagadic, L., Caquet, Th, Amiard, JC, Ramade, F, 1998. Utilisation de biomarqueurs pour la surveillance de la qualité de l'environnement [ Use of biomarkers for monitoring the quality of the environment.]. Tec \& Doc Lavoisier.

Laperche, V., Bodénan, F., Dictor, M.C., Baranger, P., 2003. Guide méthodologique de l'arsenic, appliqué à la gestion des sites et sols pollués. BRGM/RP-52066-FR, 90 p., 5 fig., 10 tabl., 3 ann [Methodological guide to arsenic, applied to the management of polluted sites and soils. BRGM / RP-52066-EN, 90 p., 5 fig., 10 tabl., 3 ann] [WWW Document]. URL http://infoterre.brgm.fr/rapports/RP-52066-FR.pdf (accessed 12.23.16).

Li, H., Ye, Z.H., Wei, Z.J., Wong, M.H., 2011. Root porosity and radial oxygen loss related to arsenic tolerance and uptake in wetland plants. Environ. Pollut. 159, 30-37. https://doi.org/10.1016/j.envpol.2010.09.031

Li, N., Wang, J., Song, W.-Y., 2016. Arsenic Uptake and Translocation in Plants. Plant Cell Physiol. 57, 4-13. https://doi.org/10.1093/pcp/pcv143

Liu, X., Zhang, S., Shan, X., Zhu, Y.-G., 2005. Toxicity of arsenate and arsenite on germination, seedling growth and amylolytic activity of wheat. Chemosphere 61, 293-301. https://doi.org/10.1016/j.chemosphere.2005.01.088

Madsen, J.D., Chambers, P.A., James, W.F., Koch, E.W., Westlake, D.F., 2001. The interaction between water movement, sediment dynamics and submersed macrophytes. Hydrobiologia 444, 71-84. https://doi.org/10.1023/A:1017520800568 
Mallick, S., Sinam, G., Sinha, S., 2011. Study on arsenate tolerant and sensitive cultivars of Zea mays L.: Differential detoxification mechanism and effect on nutrients status. Ecotoxicol. Environ. Saf. 74, 1316-1324. https://doi.org/10.1016/j.ecoenv.2011.02.012

Mazej, Z., Germ, M., 2009. Trace element accumulation and distribution in four aquatic macrophytes.

Chemosphere

74 ,

$642-647$. https://doi.org/10.1016/j.chemosphere.2008.10.019

Mazhoudi, S., Chaoui, A., Ghorbal, M.H., El Ferjani, E., 1997. Response of antioxidant enzymes to excess copper in tomato (Lycopersicon esculentum, Mill.). Plant Sci. 127, 129-137.

Meharg, A.A., Macnair, M.R., 1992. Suppression of the high affinity phosphate uptake system: a mechanism of arsenate tolerance in Holcus lanatus L. J. Exp. Bot. 43, 519-524.

Mkandawire, M., Dudel, E.G., 2005. Accumulation of arsenic in Lemna gibba L. (duckweed) in tailing waters of two abandoned uranium mining sites in Saxony, Germany. Sci. Total Environ. 336, 81-89. https://doi.org/10.1016/j.scitotenv.2004.06.002

MTES et Agences de l'eau, 2003. Système d'évaluation de la qualité de l'eau des cours d'eau SEQ-Eau, Grilles d'évaluation version 2,21 mars 2003 [Water quality assessment system for watercourses SEQ-Water, Evaluation grids version 2, 21 March 2003] [WWW Document]. URL http://www.observatoire-eau-bretagne.fr/Ressources-etdocumentation/Documents-de-planification/Systeme-d-evaluation-de-la-qualite-de-l-eaudes-cours-d-eau-SEQ-Eau (accessed 12.23.16).

Murashige, T., Skoog, F., 1962. A revised medium for rapid growth and bio assays with tobacco tissue cultures. Physiol. Plant. 15, 473-497. https://doi.org/10.1111/j.13993054.1962.tb08052.x 
Patra, M., Bhowmik, N., Bandopadhyay, B., Sharma, A., 2004. Comparison of mercury, lead and arsenic with respect to genotoxic effects on plant systems and the development of genetic tolerance. Environ.

Exp.

Bot.

52 ,

$199-223$. https://doi.org/10.1016/j.envexpbot.2004.02.009

Pollard, A.J., Reeves, R.D., Baker, A.J.M., 2014. Facultative hyperaccumulation of heavy metals and metalloids. Plant Sci. 217-218, 8-17. https://doi.org/10.1016/j.plantsci.2013.11.011

Prasad, M.N.V., Malec, P., Waloszek, A., Bojko, M., Strzałka, K., 2001. Physiological responses of Lemna trisulca L. (duckweed) to cadmium and copper bioaccumulation. Plant Sci. 161, 881-889. https://doi.org/10.1016/S0168-9452(01)00478-2

Punshon, T., Jackson, B.P., Meharg, A.A., Warczack, T., Scheckel, K., Guerinot, M.L., 2017. Understanding arsenic dynamics in agronomic systems to predict and prevent uptake by crop plants. Sci. Total Environ. 581-582, 209-220. https://doi.org/10.1016/j.scitotenv.2016.12.111

Rahman, M.A., Hasegawa, H., Mahfuzur Rahman, M., Nazrul Islam, M., Majid Miah, M.A., Tasmen, A., 2007a. Effect of arsenic on photosynthesis, growth and yield of five widely cultivated rice (Oryza sativa L.) varieties in Bangladesh. Chemosphere 67, 1072-1079. https://doi.org/10.1016/j.chemosphere.2006.11.061

Rahman, M.A., Hasegawa, H., Ueda, K., Maki, T., Okumura, C., Rahman, M.M., 2007b. Arsenic accumulation in duckweed (Spirodela polyrhiza L.): A good option for phytoremediation. Chemosphere 69, 493-499. https://doi.org/10.1016/j.chemosphere.2007.04.019

Robinson, B., Kim, N., Marchetti, M., Moni, C., Schroeter, L., van den Dijssel, C., Milne, G., Clothier, B., 2006. Arsenic hyperaccumulation by aquatic macrophytes in the Taupo 
600

601

602

603

604

605

606

607

608

609

610

611

612

613

614

615

616

617

618

619

620

Volcanic Zone, New Zealand. Environ. Exp. Bot. 58, 206-215. https://doi.org/10.1016/j.envexpbot.2005.08.004

Sharma, P., Dubey, R.S., 2005. Lead toxicity in plants. Braz J Plant Physiol 17, 35-52.

Sharma, Sohn, M., 2009. Aquatic arsenic: Toxicity, speciation, transformations, and remediation. Environ. Int. 35, 743-759. https://doi.org/10.1016/j.envint.2009.01.005

Singh, H.P., Kaur, S., Batish, D.R., Sharma, V.P., Sharma, N., Kohli, R.K., 2009. Nitric oxide alleviates arsenic toxicity by reducing oxidative damage in the roots of Oryza sativa (rice). Nitric Oxide 20, 289-297. https://doi.org/10.1016/j.niox.2009.02.004

Singh, R., Singh, S., Parihar, P., Singh, V.P., Prasad, S.M., 2015. Arsenic contamination, consequences and remediation techniques: A review. Ecotoxicol. Environ. Saf. 112, 247270. https://doi.org/10.1016/j.ecoenv.2014.10.009

Srivastava, S., Srivastava, A.K., Singh, B., Suprasanna, P., D'souza, S.F., 2013. The effect of arsenic on pigment composition and photosynthesis in Hydrilla verticillata. Biol. Plant. 57, 385-389. https://doi.org/10.1007/s10535-012-0288-7

Stoeva, N., Berova, M., Zlatev, Z., 2005. Effect of arsenic on some physiological parameters in bean plants. Biol. Plant. 49, 293-296.

Stoeva, N., Bineva, T., 2003. Oxidative changes and photosynthesis in oat plants grown in Ascontaminated soil. Bulg J Plant Physiol 29, 87-95.

Strand J.A., Weisner S.E.B. 2001.Morphological plastic responses to water depth and wave exposure in an aquatic plant (Myriophyllum spicatum) J. Ecol. 89(2):166-175. https://doi.org/10.1046/j.1365-2745.2001.00530.x 
621

622

623

624

625

626

627

628

629

630

631

632

633

634

635

636

637

638

639

640

641

642

Tangahu, B.V., Sheikh Abdullah, S.R., Basri, H., Idris, M., Anuar, N., Mukhlisin, M., 2011. A Review on Heavy Metals (As, $\mathrm{Pb}$, and $\mathrm{Hg}$ ) Uptake by plants through phytoremediation. Int. J. Chem. Eng. 2011, e939161. https://doi.org/10.1155/2011/939161

Tawfik, D.S., Viola, R.E., 2011. Arsenate replacing phosphate: alternative life chemistries and ion promiscuity. Biochemistry (Mosc.) 50, 1128-1134. https://doi.org/10.1021/bi200002a

Tripathi, R.D., Singh, R., Tripathi, P., Dwivedi, S., Chauhan, R., Adhikari, B., Trivedi, P.K., 2014. Arsenic accumulation and tolerance in rootless macrophyte Najas indica are mediated through antioxidants, amino acids and phytochelatins. Aquat. Toxicol. 157, 7080. https://doi.org/10.1016/j.aquatox.2014.09.011

Upadhyay, R.K., Panda, S.K., 2009. Copper-induced growth inhibition, oxidative stress and ultrastructural alterations in freshly grown water lettuce (Pistia stratiotes L.). C. R. Biol. 332, 623-632. https://doi.org/10.1016/j.crvi.2009.03.001

Villaescusa, I., Bollinger, J.-C., 2008. Arsenic in drinking water: sources, occurrence and health effects (a review). Rev. Environ. Sci. Biotechnol. 7, 307-323. https://doi.org/10.1007/s11157-008-9138-7

Vromman, D., Flores-Bavestrello, A., Šlejkovec, Z., Lapaille, S., Teixeira-Cardoso, C., Briceño, M., Kumar, M., Martínez, J.-P., Lutts, S., 2011. Arsenic accumulation and distribution in relation to young seedling growth in Atriplex atacamensis Phil. Sci. Total Environ. 412413, 286-295. https://doi.org/10.1016/j.scitotenv.2011.09.085

Xue, P., Yan, C., 2011. Arsenic accumulation and translocation in the submerged macrophyte Hydrilla verticillata (L.f.) Royle. Chemosphere 85, 1176-1181. https://doi.org/10.1016/j.chemosphere.2011.09.051 
643

644

645

646

647

648

649

650

651

652

653

654

655

656

657

658

Yabanli, M., Yozukmaz, A., Sel, F., 2014. Heavy metal accumulation in the leaves, stem and root of the invasive submerged macrophyte Myriophyllum spicatum L. (Haloragaceae): An Example of Kadın Creek (Mugla, Turkey). Braz. Arch. Biol. Technol. 57. https://doi.org/10.1590/S1516-8913201401962

Zhang, W., Cai, Y., Tu, C., Ma, L.Q., 2002. Arsenic speciation and distribution in an arsenic hyperaccumulating plant. Sci. Total Environ. 300, 167-177. https://doi.org/10.1016/S0048-9697(02)00165-1

Zhao, F.J., Ma, J.F., Meharg, A.A., McGrath, S.P., 2009. Arsenic uptake and metabolism in plants: Tansley review. New Phytol. 181, 777-794. https://doi.org/10.1111/j.14698137.2008.02716.x

Zhou, B., Wang, J., Guo, Z., Tan, H., Zhu, X., 2006. A simple colorimetric method for determination of hydrogen peroxide in plant tissues. Plant Growth Regul. 49, 113-118. https://doi.org/10.1007/s10725-006-9000-2 
659

660

661

662

663

664

665

666

667

668

669

670

671

672

673

674

675

676

677

678

679 Figure 3: Effect of arsenic supply on the osmotic potential ( $\Psi$ scor) $\mu$ osmol.kg ${ }^{-1} \mathrm{H}_{2} \mathrm{O}$ ) in shoots 680

\section{List of figures}

Figure 1: Effect of arsenic supply on hydrogen peroxide $\left(\mathrm{H}_{2} \mathrm{O}_{2}\right)$ content $(\mu \mathrm{M}$ based on $\mathrm{FW})$ in shoots of watermilfoil plants - Controls and Treated with $100 \mu \mathrm{g} . \mathrm{L}^{-1}$ As in a recirculated system at 21 days. The values shown are means \pm standard error of three independent experiments $\left(\mathrm{N}=9\right.$ ). The uppercase letters compare the $\mathrm{H}_{2} \mathrm{O}_{2}$ concentrations at the same plant parts (old or young) across the hydrodynamic zones, while lowercase letters compare the $\mathrm{H}_{2} \mathrm{O}_{2}$ concentrations within the same hydrodynamic zone between the different plant parts (old vs. young) on the Control and As-treated plants. The means followed by the same letter do not differ in the Sidak test at a 5\% significance level.

Figure 2: Effect of arsenic supply on pigment contents (in $\mu \mathrm{g} \cdot \mathrm{g}^{-1} \mathrm{FW}$ ) in shoots of watermilfoil plants - Controls and Treated with $100 \mu \mathrm{g} . \mathrm{L}^{-1}$ As in a recirculated system at 21 days. The values shown are means \pm standard error of three independent experiments $(\mathrm{N}=9)$. The uppercase letters compare the pigment concentrations at the same plant parts (old or young) across the hydrodynamic zones, while lowercase letters compare the pigment concentrations within the same hydrodynamic zone between the different plant parts (old vs. young) on the Control and As-treated plants. The means followed by the same letter do not differ in the Sidak test at a 5\% significance level. (FW: Fresh Weight, Chl a: chlorophyll a, Chl b: chlorophyll b, car: carotenoid)

$$
\text { of watermilfoil plants - Controls and Treated with } 100 \mu \mathrm{g} . \mathrm{L}^{-1} \text { As in a recirculated system at } 21
$$
days. The values shown are means \pm standard error of three independent experiments $(\mathrm{N}=9)$. The uppercase letters compare the osmotic potential at the same plant parts (old or young) across the 
683

684

685

686

687

688

689

690

691

692

693

694

695

696

697

698

699

700

701

702

703

704

various hydrodynamic zones, while lowercase letters compare the osmotic potential within the same hydrodynamic zone between the different plant parts (old vs. young) on the Control and As-treated plants. The means followed by the same letter do not differ in the Sidak test at a 5\% significance level.

Figure 4: Effect of arsenic supply on the net photosynthesis and respiration in the watermilfoil plants - Controls and Treated with $100 \mu \mathrm{g} . \mathrm{L}^{-1}$ As in a recirculated system. The values shown are means \pm standard error of three independent experiments $(\mathrm{N}=9)$, expressed in $m m o l O_{2} \cdot \mathrm{mL}^{-1} \mathrm{~s}^{-1} \cdot \mathrm{g}^{-}$ ${ }^{1}$ FW. Net photosynthesis (NP), Respiration (Res). The uppercase letters compare the respiratory and photosynthetic activities in the control and As-treated plants separately across hydrodynamic zones, while lowercase letters compare the respiratory and photosynthetic activities within the same hydrodynamic zone between the Control and As-treated plants. The means followed by the same letter do not differ in the Sidak test at a 5\% significance level.

Figure 5: Effect of arsenic supply on the mean total main stem length (SL) (A) and mean total root length (RL) (B) of watermilfoil plants - Controls and Treated with $100 \mu \mathrm{g} . \mathrm{L}^{-1}$ As in a recirculated system for 19 days. The values shown are means \pm standard error of three independent experiments $(\mathrm{N}=18)$, expressed in $\mathrm{cm}$. The uppercase letters compare the SL and $\mathrm{RL}$ in the control and As-treated plants separately across hydrodynamic zones, while lowercase letters compare the SL and RL within the same hydrodynamic zone between the Control and Astreated plants. The means followed by the same letter do not differ in the Sidak test at a $5 \%$ significance level. Inter: intermediate, Lam: Laminar. 


\section{List of tables:}

707 Table 1: Arsenic accumulation (in $\mu \mathrm{g} \cdot \mathrm{g}^{-1} \mathrm{DW}$ ) and bioconcentration factor (BCF, in $\mathrm{L}^{\mathrm{kg}} \mathrm{kg}^{-1}$ ) in 708 the shoots and roots of watermilfoil plants - Controls and Treated with $100 \mu \mathrm{g} . \mathrm{L}^{-1}$ As in a 709 recirculated system by considering three hydrodynamic conditions (calm, turbulent and laminar) 710 at 21 days. The values shown are means \pm standard error of three independent experiments 711 ( $\mathrm{N}=6)$. The uppercase letters compare the arsenic concentration for the same plant parts across 712 the various hydrodynamic zones, while lowercase letters compare the arsenic concentration 713 within the same hydrodynamic zone across the various plant parts. The means followed by the 714 same letter do not differ in the Bonferroni test at a 5\% significance level. 


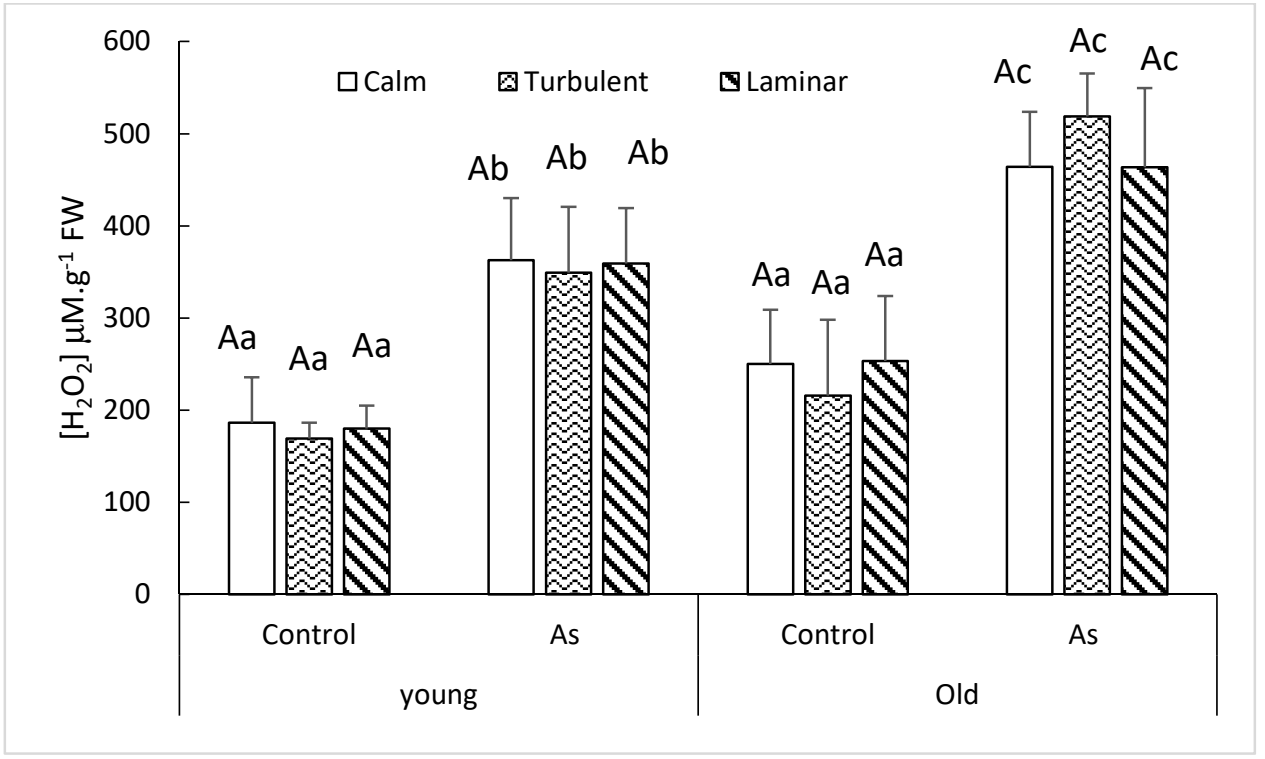




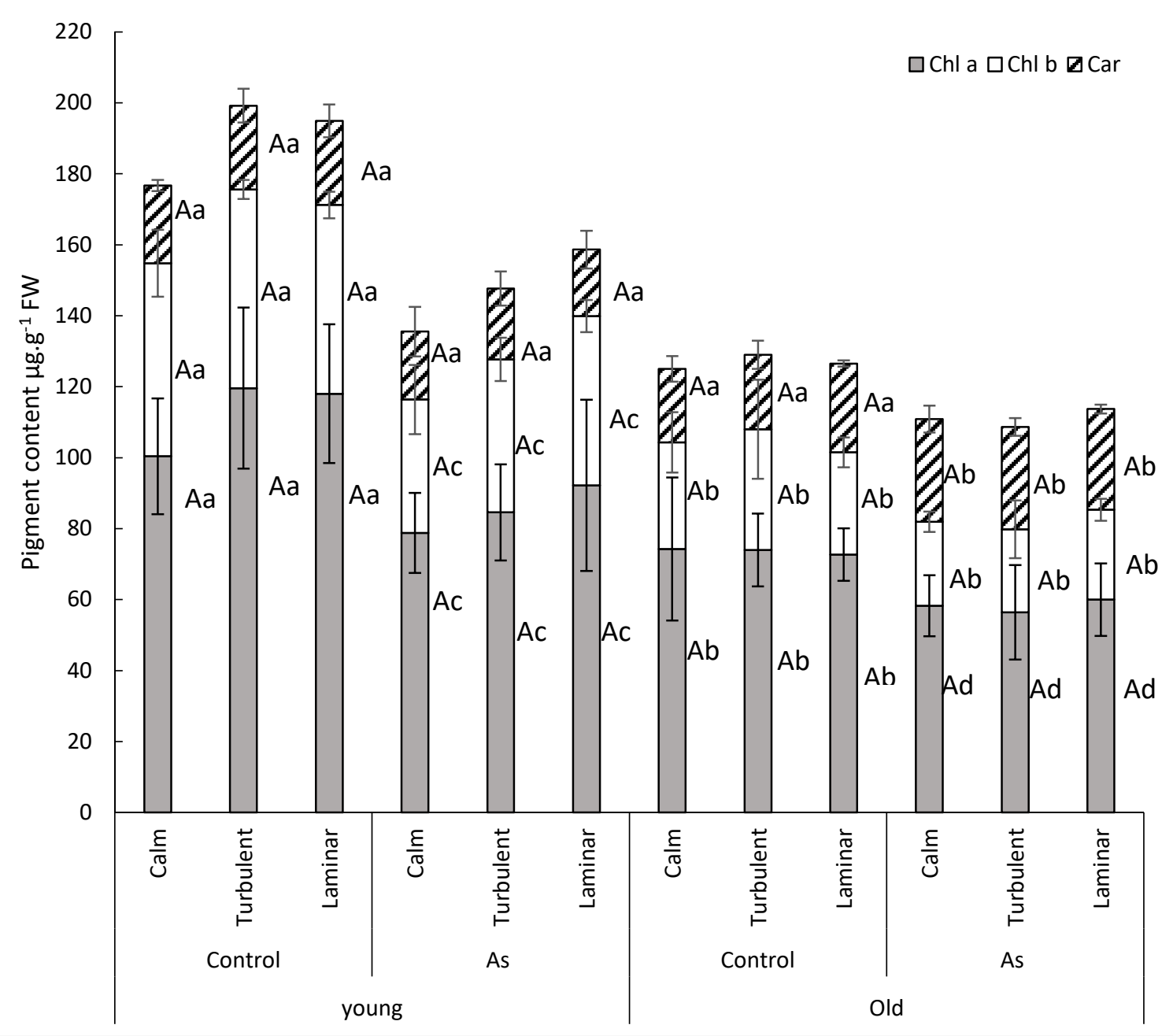




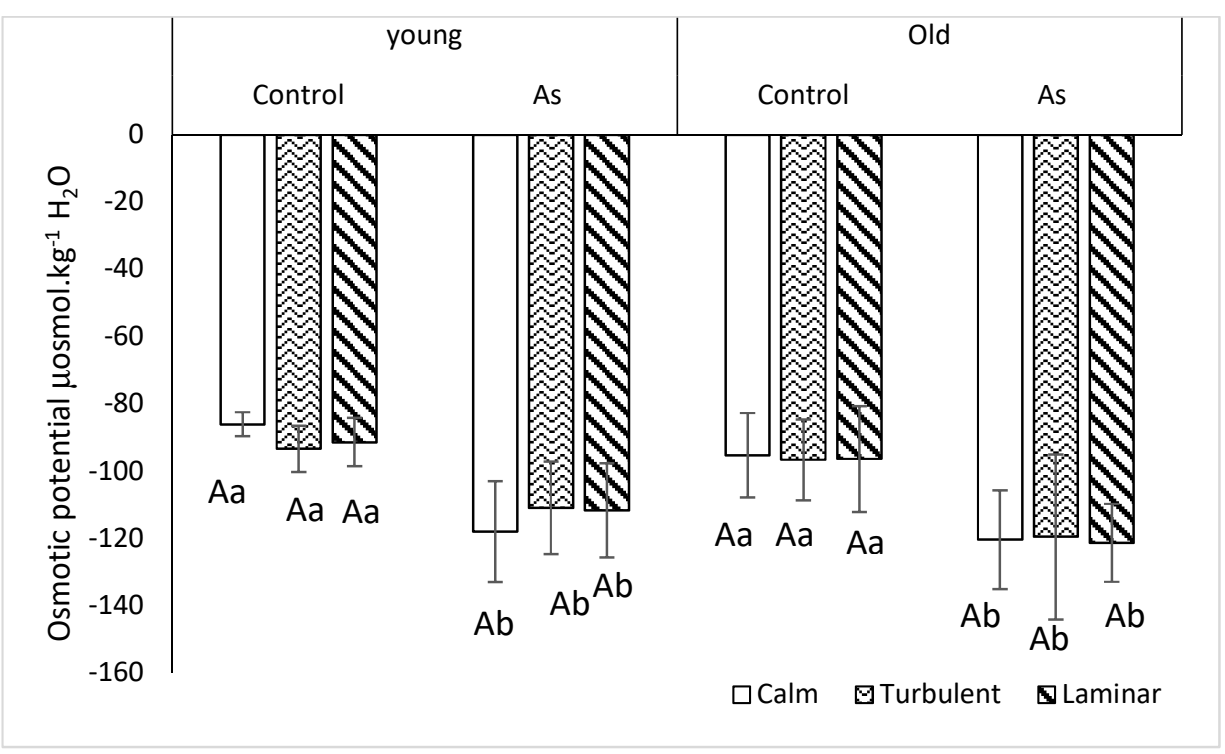




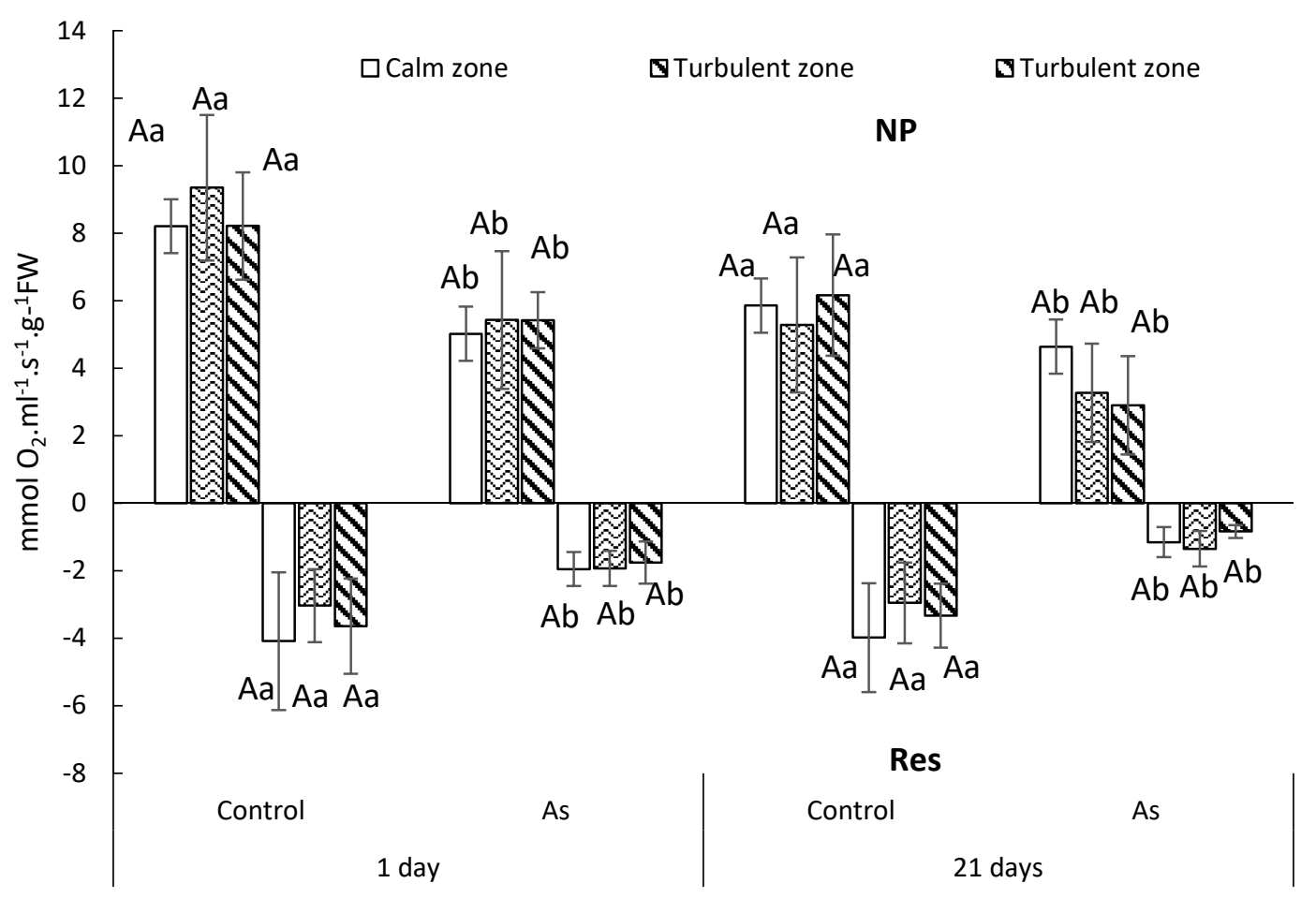


A

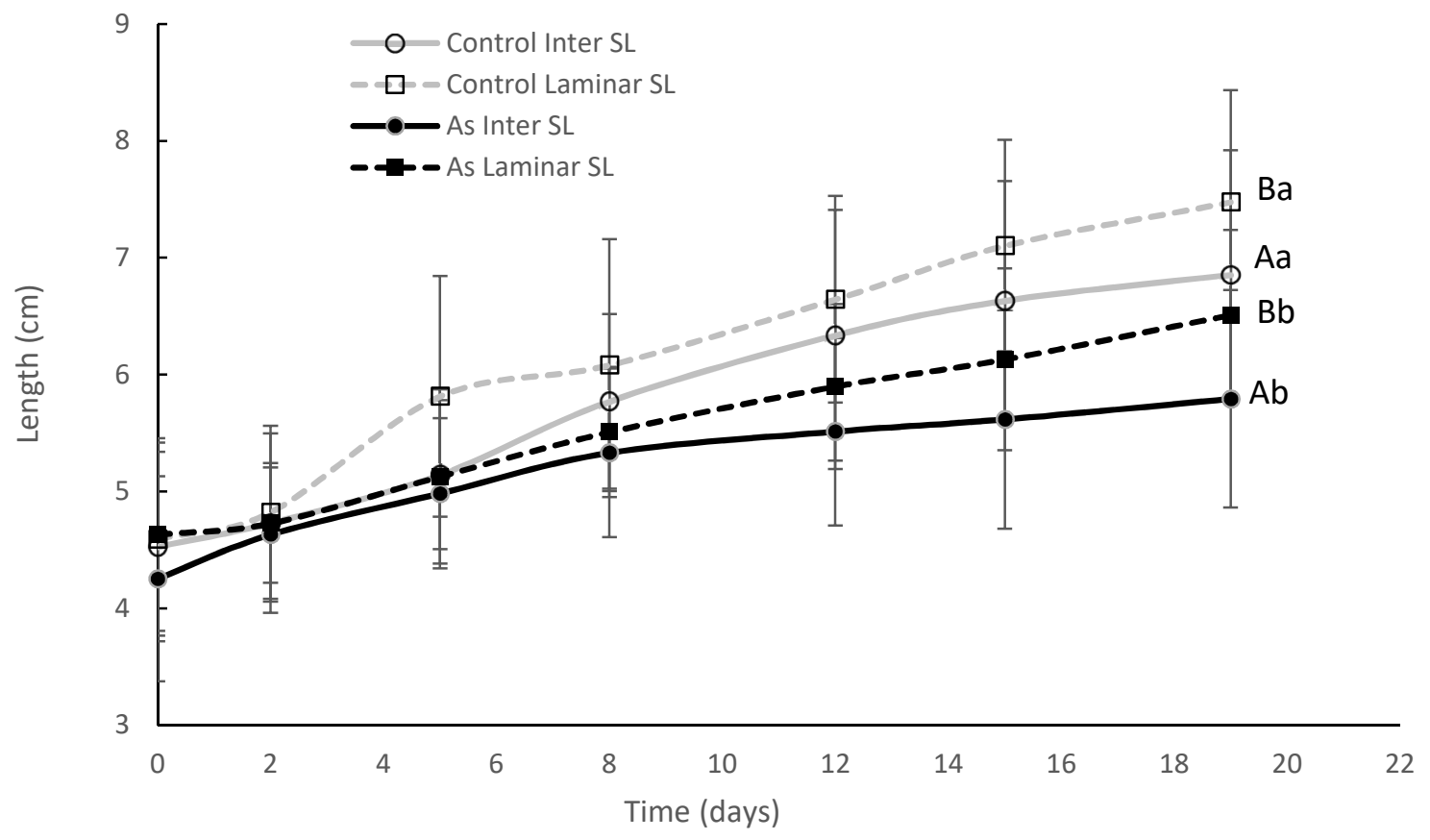

B

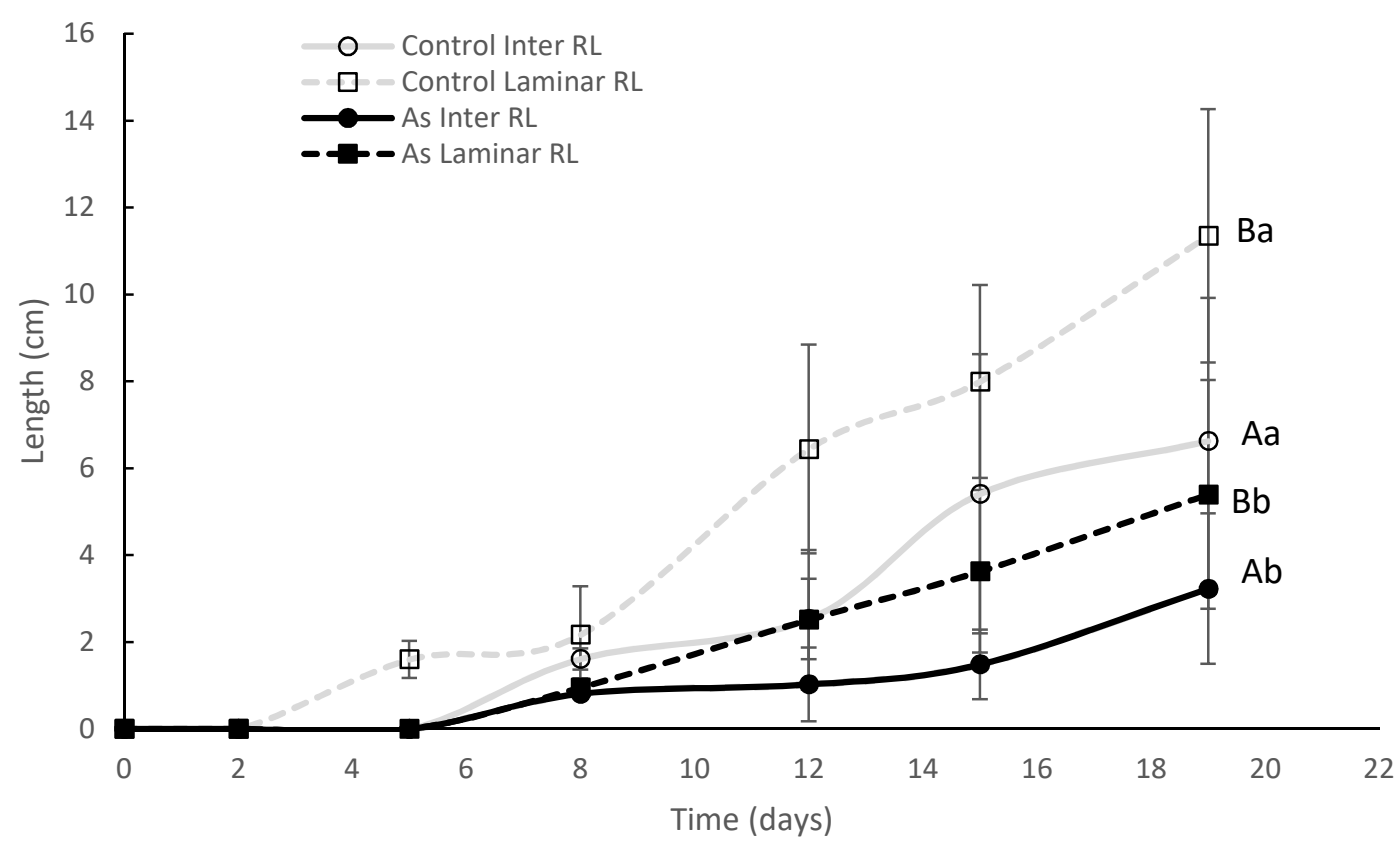




\begin{tabular}{|c|c|c|c|c|}
\hline \multirow{4}{*}{$\begin{array}{c}{[\mathrm{As}]} \\
\mu \mathrm{g} . \mathrm{g}^{-1} \mathrm{DW}\end{array}$} & \multirow{3}{*}{$\begin{array}{c}\text { Plant parts } \\
\text { Stem+ leaves }\end{array}$} & \multirow{3}{*}{$\begin{array}{l}\text { Calm zone } \\
218 \pm 1^{\mathrm{Aa}}\end{array}$} & \multicolumn{2}{|c|}{ Hydrodynamic conditions } \\
\hline & & & Turbulent zone & Laminar zone \\
\hline & & & $200 \pm 1^{\mathrm{Bc}}$ & $218 \pm 2 \mathrm{Ae}$ \\
\hline & Root & $500 \pm 2^{\mathrm{Ab}}$ & $459 \pm 1 \mathrm{Bd}$ & $387 \pm 1 \mathrm{Cf}$ \\
\hline \multirow[t]{2}{*}{ BCF $\left(\mathrm{L} \cdot \mathrm{kg}^{-1}\right)$} & Stem+ leaves & $176 \pm 40^{\mathrm{Aa}}$ & $172 \pm 60^{\mathrm{Aa}}$ & $169 \pm 70^{\mathrm{Aa}}$ \\
\hline & Root & $414 \pm 80^{\mathrm{Ab}}$ & $346 \pm 50^{\mathrm{Bb}}$ & $308 \pm 44 \mathrm{Cb}$ \\
\hline
\end{tabular}

